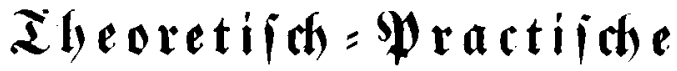

\section{(9) $\mathbf{r}$ m $\mathbf{m}$ a $\mathbf{t} \mathbf{i}$ \\ $\operatorname{ser}$ \\ (E) Itisclen Spractye}

fin t

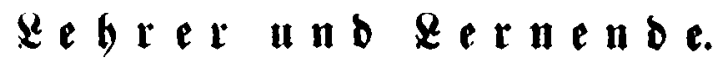

$\mathfrak{B}$ on

Con a 2 a

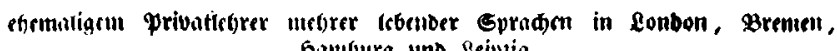
Sointurutg uno ecipsig.

\section{bie te}

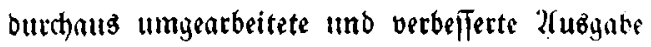

Don

Johann $\mathfrak{s p a r a t h i l . ~}$

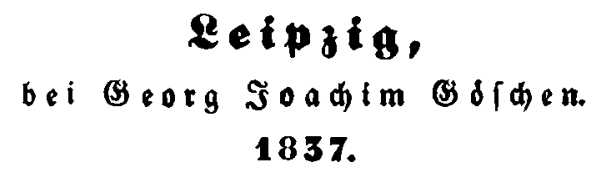


